\title{
Business Model: Literature Review
}

\author{
Afzal Sayed Munna \\ Module Leader and Academic Coordinator University of Wales Trinity Saint David, London, United \\ Kingdom \\ Email: a.munna@uwtsd.ac.uk
}

(Received: December-2020; Reviewed: January-2021; Accepted: January-2021;

Avalaible Online: January-2021; Published: January-2021)

(7) (9) This is an open access article distributed under the Creative Commons Attribution License

CC-BY-NC-4.0 @2020 by author (https://creativecommons.org/licenses/by-nc/4.0/)

\begin{abstract}
The term Business Model has been in use for many years which is a scientific method of being creative and innovative in creating successful business. The aim of this literature review is to define the theory relating to the business model (which includes various definitions from business and economic perspectives) and create a real-life analytical tool to define the characteristics of each part of business model, i.e., customers, distribution, value, resources, activities, cost and revenue.
\end{abstract}

Keywords: Business model; value proposition; resources; revenue.

\section{INTRODUCTION}

Post-industrial $21^{\text {st }}$ century has been described as one of the most fragmented and dynamic business environments. The nature and motive of industry and market has been changed radically and so do the focus of the customer/consumer requirements. Due to the massive industrialisation and the consumer trend shift many companies are now not only changed their marker strategy, but also brought changes on their culture, ways of selling and relationship building. The companies are utilising the concept of value-based branding and creating competitive differentiations in the local/international/global market. The review thus aimed to analyse the business systems, new trends and changes that impact/or important to consider while implementing the business model and concept.

\section{LITERATURE REVIEW}

\section{Business Model: Concepts}

Financial Journalist Michael Lewis first introduced the term business model in his article where he predicted that every business is an outcome of financial nature and the model will 
mostly be relied on internet (might be the introduction of e-commerce). On the other hand, Teece (2010) defines business model as one of the theoretical foundations in economics. However, analysing different author's view the researcher has revealed that, business model is not only the process of creating value but also is an economic concept, which "produces" revenues and costs. It is a set of activities, which create profit due to the cooperation of processes and technologies. We have articulated few widely used definitions which are depicted below (refer to table 1)

Table 1 Economic Business Model

\begin{tabular}{|c|c|}
\hline Author & Definition \\
\hline Allan Afuah & $\begin{array}{l}\text { Business model can be seen as a framework for making money. It is the } \\
\text { set of activities which a firm performs, how it performs them and when it } \\
\text { performs them so as to offer its customers benefits, they want and to earn } \\
\text { a profit (Afuah, 2003) }\end{array}$ \\
\hline $\begin{array}{l}\text { Baden-Fuller \& } \\
\text { Morgan }\end{array}$ & $\begin{array}{l}\text { Business model is a profit formula, system of business and learning } \\
\text { System (Baden-Fuller \& Morgan, 2010) }\end{array}$ \\
\hline $\begin{array}{l}\text { John Mullins \& } \\
\text { Randy Komisar }\end{array}$ & $\begin{array}{l}\text { Business model is the pattern of economic activity - cash flowing into } \\
\text { and out of your business for various purposes and the timing thereof - that } \\
\text { dictates whether or not you run out of cash and whether or not you deliver } \\
\text { attractive returns to your investors. In short, your business model is the } \\
\text { economic underpinning of your business, in all of its facets (Mullins \& } \\
\text { Komisar, 2009) }\end{array}$ \\
\hline Henry Chesbrough & $\begin{array}{l}\text { The business model is a useful framework to link ideas and technologies } \\
\text { to economic outcomes (Chesbrough, 2006) }\end{array}$ \\
\hline Don Debelak & $\begin{array}{l}\text { A business model is the instrument by which a business intends to } \\
\text { generate revenue and profits. It is a summary of how a company means to } \\
\text { serve its employees and customers and involves both strategy as well as } \\
\text { an implementation (Debelak, 2006) }\end{array}$ \\
\hline $\begin{array}{l}\text { Alfonso } \\
\text { Ganbardella } \\
\text { Anita McGahan }\end{array}$ & $\begin{array}{l}\text { Business model is a mechanism for transformation ideas to revenues } \\
\text { through the acceptable costs (Alfonso et } \mathrm{al}, 2010 \text { ) }\end{array}$ \\
\hline $\begin{array}{l}\text { Thomas Wheelen } \\
\text { David Hunger }\end{array}$ & $\begin{array}{l}\text { Business model is a method for making money in the concrete business } \\
\text { environment. It is consisted of key structural and operational } \\
\text { characteristics of company - how company earn and create profit } \\
\text { (Wheelen \& Hunger, 2008) }\end{array}$ \\
\hline
\end{tabular}

The above table (table 1) represents the definitions from an economic perspective which is not connected to the complexity of the concept and thus we have decided to articulate few more definitions from value creation concept (refer to table 2).

Table 2 Economic and Value Business Model

Author Definition

\begin{tabular}{ll}
\hline David Watson & $\begin{array}{l}\text { A business model describes operations of company, including all of its } \\
\text { components, functions and processes, which result in costs for itself and } \\
\text { value for customer (Watson, 2005) }\end{array}$ \\
David J. Teece & $\begin{array}{l}\text { Business model defines how a company provide value to customer and } \\
\text { transfer payments to profit (Teece, 2010) }\end{array}$ \\
Joan Magretta & \begin{tabular}{l} 
Business models are, at heart, stories that explain how enterprises work. Like \\
\hline
\end{tabular}
\end{tabular}


a good story, a robust business model contains precisely delineated characters, plausible motivations and a plot that turns on an insight about value. It answers certain questions: Who is the customer? How do we make money? What underlying economic logic explains how we can deliver value to customers at an appropriate cost? (Magretta, 2010)

Michael Rappa Business model is the method of doing business by which a company can sustain itself - that is generating revenue. The business model spells-out how a company makes money by specifying where it is positioned in the value chain (Rappa, 2010)

Alexander A business model describes the logic of how an organization creates, delivers Osterwalder and control value and how money are earned in a company (Osterwalder \& Yves Pigneur Štefan Slávik Pigneur, 2009)

The business model is a machine for making money, but money is important not only to produce but also to appropriate. Business model visualizes company as a place of decisions and consequences, it is a group of resources and activities in the varying degrees of and operational view, which result and serve to offer value to customer (Slávik, 2011)

While considering the concept of business model, the researcher realised that the model is a system approach that includes business resources and activities which create value that are useful to the customers and provide value for money. The similar concept was addressed by Mullins and Komisar (2009) where they established the model based of Five Pillars, which predetermine the economic viability of any business.

The revenue model is defined as the money that comes from a customer who is willing to buy what the company sells. Gross margin model is the difference between revenue from sales and cost for production, thus money, which lefts after payment of direct costs. Operating model includes fixed costs that are indirectly paid for production. Working capital model is a cash which must be available to ensure fluent operation until the customer pays for the goods. Investment model describes the usage of money that the company wants to invest for the development of business.

The similar concept was addressed by Alan Afuah (2003) who has created the model based on 4 components (refer to figure 1), where all the components are equally responsible for generating profitability. The model works as a chain of workflows where resources help to create value differentiation. Cost brings new type of value - low-cost model. Positions are about looking for the right places, which are not occupied, or the company can deliver to the existing market new, interesting values. Cooperation of these components creates a successful business model, and their uniqueness is a source of competitive advantage. 


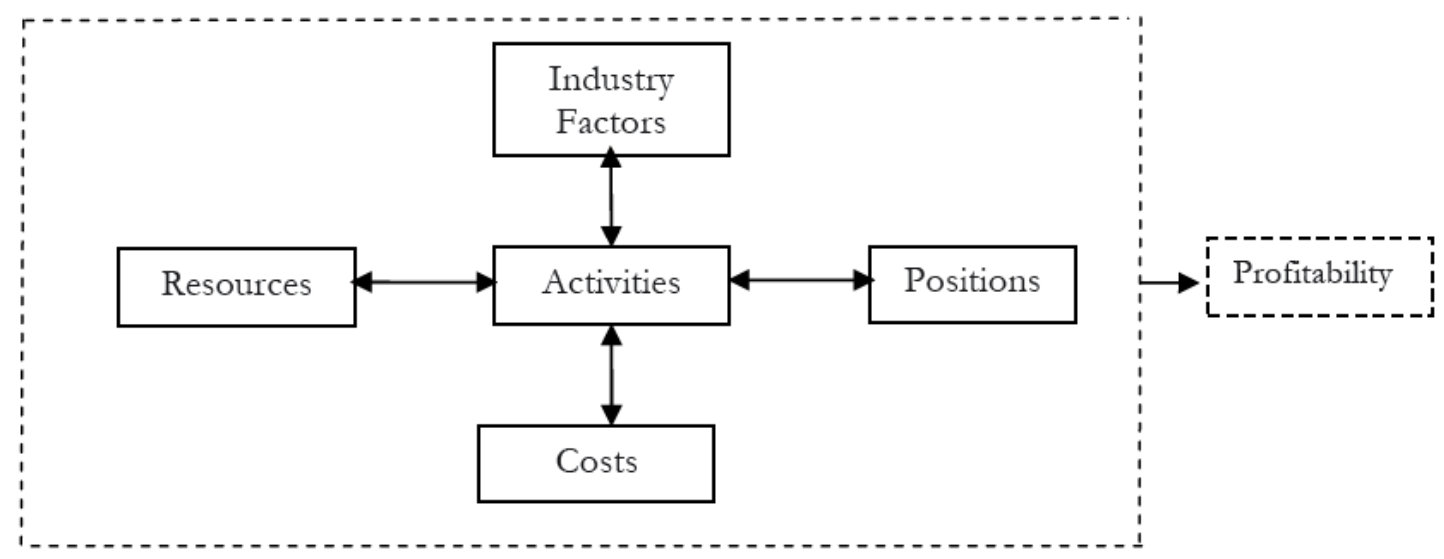

Figure 1. Components of business model by A. Afuab (2003)

As the researcher discussed and defined various concepts and along with many the above model is not free from limitations and weaknesses. One of the limitations of the model is that the model does not address the company as a complex system. It also does not create any connection of components into causal chain that would demonstrate the connectivity and bonds of elements. The concept does not allow the clear practical application to concrete numerical results (Slávik, 2011).

On the other hand, David Watson (2005) developed six component-based business model where he mentioned that each component is unique and while analysing the elements from the model the term competitors are defined by barriers of entry to market, threat of substitute products, competition within the industry and the advantage of being the first in the market (similar to the Porter's Five Force Model). Customers are evaluated according to their characteristics, types of contracts and payment rates. Economy of company is analysed considering to acquisitions, economies of scale, earning on the growth of another company, dividends and breakpoint. Management is evaluated by the moral view, conflicts checking, accounting rules, success in the past and relationship with partners. Products is focused on the brand loyalty, competitive advantage, creating new products, differentiation, sale places and innovation of value chain. Suppliers are defined by their negotiation power and opportunistic buying. Along with many other limitations the model allows the business to analyse the sector factors, such as competitors and environment.

Johnson et al, (2008) on the other hand explained the business model using as a set of four components, which are interconnected: value for a customer, profit formula, key resources and key activities. According to Johnson et al a successful business will utilise its organisational resources (people, technologies, tangible and intangible asset, brand) and doing the right activities (trainings, development, production, budgeting, planning and selling) to create value to the business. Following Johnson, Alexander Osterwalder and Yves Pigneur, created a model that they called Canvas. The use of Canvas defines business model using nine components: customer segments, customer relationships, distribution channels, value proposition, key resources, key activities, partners, cost structure and revenue streams and being used as a visualization tool that shows components interrelationship (refer to figure 2). The model analyses the factors which are interconnected to create value to the business by analysing its key activities and resources. 


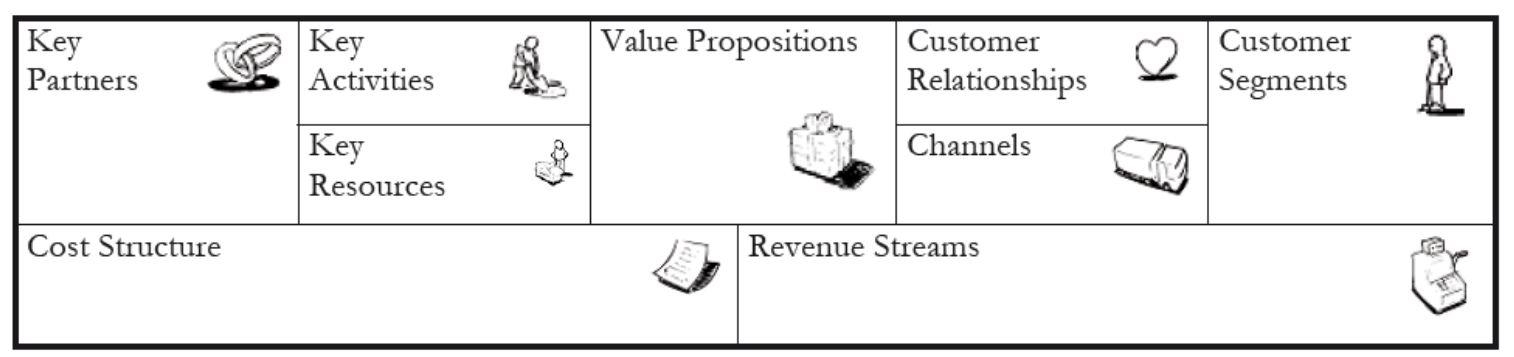

Figure 2. The visualization tool canvas by Osteralder and Pigneur (2009)

\section{Business Model Innovation}

Business Model Innovation is the key stream and also often treated as the implicit part for conceptualisation. It was captured from the literature review and research from Schallmo (2013) and Mitchell and Coles (2003) that the business model innovation help increase the resilience and also help constitute a sustainable competitive advantage. According to Schaltegger et al, (2012) business model innovations require systematic and ongoing creation of business cases to ensure the sustainability. And business sustainability can be ensured by applying pro-active sustainability strategies with business model adjustment, adoption, improvement, and redesign which was also stated by Geissdoerfer et al., 2016).

\section{Discussion}

Business Model/Business Modelling is very useful for value creation which associates all activities including business processing, designing, finding and reaching customers, transacting a sale, distributing the product, or service delivery. The literature also revealed that a new business model also may turn on designing a new product or lead to a process innovation. Introducing a better business model can help business to ensure the divarication of product and or business unit to an existing or another market (Ritter \& Pedersen, 2020). The primary goal of any business model is to create a sustainable chain and also unlock the value for market players. This value can be measured by value proposition or by the promise from the key players and partners in the market (Seetharaman, 2020). It was also found that business model is a critical element for any start-up success and thus developing a business model is not only the monetization strategies or but also being very holistic ensure value addition and help grow the business.

\section{CONCLUSION}

Dynamics and evolution of the current business environment always push forward fundamental contemplation and also analyse the conditions for business survival. However, the analysis through visualisation and reconstruction of the business model remains the primary goal of every business for creating business strategies and process improvements. It was revealed that the success of the business model depends on creating value for money to its customers/consumers. The literature reveals comprehensive advantages that business models (often a sustainable business model) have for organisations. The author agrees that a sustainable business model not only ensure productivity but also ensure sustainable competitive advantage. It was also indicated that continuous development of contemporary technologies constantly brings fundamental changes to the business model and thus development of innovative business 
models is very much needed in the $21^{\text {st }}$ century. Therefore, the conceptual advances of this review have become increasingly relevant for the field at large.

\section{REFERENCES}

Afuah, A. (2003) Business Models: A Strategic Management Approach. New York: McGrawHill.

Baden-Fuller, CH. \& Morgan, M. S. (2010) Business Models as Models. Long Range Planning, 43(2), 156-171. http://dx.doi.org/10.1016/j.lrp.2010.02.005

Chesbrough, H. (2006) Open Business Models: How to Thrive in the New Innovation Landscape. Boston: Harvard Business School Press.

Debelak, D. (2006) Business model made easy. Wisconsin: CWL Publishing Enterprises.

Geissdoerfer, M., Bocken, N.M.P., Hultink, E.J., (2016). Design thinking to enhance the sustainable business modelling process. J. Clean. Prod. 135, 1218e1232. https:// doi.org/10.1016/j.jclepro.2016.07.020.

Hunger, D. L. \& Wheelen, T. L. (2008) Concepts: Strategic Management and Business Policy. New Jersey: Prentice Hall.

Johnson, W. M., Christensen, C. M. \& Kagerman, H. (2008) Reinventing Your Business Model. Harvard business review, 86(12), 57-68.

Magretta, J. (2010) Why Business Models Matter. Harvard Business Review on Business Model Innovation. USA: HBR Publishing Corporation.

Mitchell, D., Coles, C., (2003). The ultimate competitive advantage of continuing business model innovation. J. Bus. Strat. 24, 15e21. https://doi.org/10.1108/ 02756660310504924.

Mullins, J. \& Komisar, R. (2009) Getting to Plan B: Breaking Through to a Better Business Model. USA: Harvard Business Press.

Osterwalder, A. \& Pigneur, Y. (2009) Business Model Generation. Self-Published.

Rappa, M. (2010) Business Models on the Web. Retrieved Jan 17, 2021, from http:// digitalenterprise.org/models/models.html

Ritter, T., \& Pedersen, C. L. (2020). Digitization capability and the digitalization of business models in business-to-business firms: Past, present, and future. Industrial Marketing Management, 86, 180-190.

Schaltegger, S., Hansen, E., Lüdeke-Freund, F., (2012). Business cases for sustainability and the role of business model innovation. Int. J. Innovat. Sustain. Dev. 6, 95e119.

Schallmo, D., (2013). Gesch€aftsmodell-Innovation: Grundlagen, bestehende Ans€atze, methodisches Vorgehen und B2B-Gesch€aftsmodelle. Springer Fachmedien Wiesbaden, Wiesbaden. https://doi.org/10.1007/978-3-658-00245-9.

Seetharaman, P. (2020). Business models shifts: Impact of Covid-19. International Journal of Information Management, 54, 102173.

Teece, J. D. (2010) Business Models, Business Strategy and Innovation. Long Range Planning, 43(2), 172-194. http://dx.doi.org/10.1016/j.lrp.2009.07.003

Watson, D. (2005) Business Models. Petersfield: Harriman House Ltd. 